\title{
Human-Wildlife Conflict In the Forest Villages of Barak Valley, Assam, India
}

\author{
H. DUTTA ${ }^{1}$, H. SINGHA ${ }^{1 *}$, B. K. DUTTA ${ }^{1}$, P. DEB ${ }^{1}$ and A. DAS ${ }^{2}$ \\ 1Department of Ecology and Environmental Science, Assam University, Silchar, \\ Assam, India. PIN- 788011, India. \\ ${ }^{2}$ Geospatial Technology \& Application Programme, Aaranyak, 50 Samanway Path, \\ Survey, Beltola, Guwahati, Assam, PIN 781 028, India. \\ http://dx.doi.org/10.12944/CWE.10.1.29
}

(Received: March 31, 2015; Accepted: April 16, 2015)

\begin{abstract}
Man and animals are frequently coming into conflicts over habitat and food requirements and this is mainly due to expanding human population and loss of natural habitats. The problem has been identified as major challenge to the governments of many countries and is significant to many human communities. Forest villages are the most potent sites for this problem as these are the places where human needs intersect with those of the wild animals. There are 104 forest villages in Barak Valley which is constituted by three districts; namely: Cachar, Hailakandi and Karimganj located in the Southern part of the Indian state of Assam. However, no proper study has yet been pursued with respect to man-wildlife conflict in these villages. Hence, present study was attempted to indentify the various wild animals which are involved in conflict in the forest villages of the region. The study revealed that there were four conflict animals; viz: jackal, civet, wild boar and monkey which were most commonly associated with the problem in these villages.
\end{abstract}

Key words: Man-animal conflict, Forest village, Barak Valley, Assam

\section{INTRODUCTION}

Biodiversity or wildlife-related conflicts are situations when wildlife comes into conflict with humans over common resources (Conover, 2002; Graham et al., 2005). According to Woodroffe et al. (2005), human-wildlife conflict is the phenomenon where conflicting situations arise between humans and wildlife in the form of crop raiding, livestock depredation, predation on managed wild animal species or killing of people. It is a serious issue that requires to be addressed urgently with utmost priority (Ministry of Environment and Forests, India, 2011).

People residing near forests as well as in forest fragments are more prone to conflicts as wild animals seek to fulfil their nutritional, ecological and behavioural needs (Sukumar, 1990). In other words, people residing in and around forests easily fall victims to conflicts with wild animals because their requirements often overlap with those of the wildlife. In fact, conflict can be particularly serious, where rural people live in close association with protected areas (Mishra, 2001). Hence, forest villages are the most potent sites for man-animal conflict. Human-wildlife conflict attracts serious attention when endangered species are involved in and when human welfare is threatened (Saberwal et al., 1994). However, other than the charismatic animals, depredation could also be caused by some commonly occurring animals which result severe consequences and losses.

There are 104 forest villages in the Barak Valley, Assam, which could be prone to humanwildlife conflict; however no study has been done 
on this issue in this region. This paper documents conflict between human and four species of wild animal, which are not endangered but have been influential in depredation in the forest villages of this Valley.

\section{MATERIALS AND METHODS}

The Barak Valley is situated between $24^{\circ} 80$ $\mathrm{N}$ and $25^{\circ} 80^{\prime} \mathrm{N}$ latitudes and $92^{\circ} 15^{\prime} \mathrm{E}$ and $93^{\circ} 15^{\prime} \mathrm{E}$ longitudes in south Assam and comprises of Cachar, Karimganj and Hailakandi districts (Figure 1). The Valley has a total area of $6962 \mathrm{~km}^{2}$ and represents $9 \%$ of the geographical area of Assam. The area is drained by the river Barak and its tributaries and is bounded by North Cachar Hills district of Assam and Jaintia Hills district of Meghalaya in the north, Mizoram in the south, Manipur in the east as well as the state of Tripura and Sylhet district of Bangladesh in the west. The valley is bounded by the Barail hills in the north, Bhuban hills in the east and the hills of Mizoram in the south. The land use comprises of agricultural activities, fishing, human settlements and grazing land. The altitudinal variation and varied climatic conditions have bestowed the area with $1 \mathrm{~B} / \mathrm{C} 3$ Cachar tropical evergreen and $2 \mathrm{~B} / \mathrm{C} 2$ Cachar tropical semi-evergreen forest (Champion and Seth, 1968). The climate of Barak Valley region is subtropical, warm and humid (Das and Joshi, 2012).

Each of the districts has its own respective forest division under which there are forest ranges to look after the forest administration. The Karimganj Division has six forest ranges, whereas Cachar and Hailakandi have five ranges each. There are twelve reserve forests and a wildlife sanctuary in the Barak valley, of which only nine i.e. Lower Jiri, Upper Jiri, Barak, Innerline, Sonai, Katakhal, Longai, Singla and Patheria hills reserve forests have forest villages located within their notified area (Source: Department of Environment \& Forests, Cachar, Karimganj and Hailakandi Division, Southern Assam). These reserve forests together encompass 104 forest villages. Karimganj Division has the highest number of forest villages (44), followed by Cachar (40) and Hailakandi Division (20). The forest villages under Karimganj Division are located under three ranges; viz: Cheragi (16), Lowairpoa (27) and Patharkandi (1). The forest villages under Cachar Division are located under four ranges; viz: Hawaithang (22), Monierkhal (6), Jirighat (8) and Sadar (4), and the forest villages under Hailakandi Division are located under three ranges; viz: Matijuri (13), Gharmurah (4) and Kukicherra (3). Longai Reserve Forest (under Lowairpoa Range) has the highest number of forest villages (27), whereas Patheria hills reserve forest (under Patherkandi Range) has the least number (1) of forest villages.

The major fauna of Barak Valley includes Indian elephant, porcupine, leopard, slow loris, macaques, squirrels, phayer's leaf monkey, sloth bear, Asiatic black bear, civets, Indian grey mongoose, wild boar, goral etc. (Choudhury, 2013).

The survey was conducted between October, 2013 and February, 2014. The list of forest villages was collected from Department of Environment \& Forests, Cachar, Karimganj and Hailakandi Division. Out of the 104 forest villages of the Valley, 52 (i.e. $50 \%$ ) were taken into consideration for detailed study. We used closed-ended questionnaire survey (Fanning, 2005; Anon, 2012). However, questions were open-ended regarding the wild animal species. From each Forest Division, $50 \%$ forest villages were surveyed, and thus, 22, 20 and 10 forest villages from Karimganj, Cachar and Hailakandi Division, respectively were surveyed (Figure 1). The forest villages to be surveyed in a particular Division were selected through the generation of random numbers from a scientific calculator in which the total number of forest villages present in that particular Division had been placed as the upper limit. The generated random numbers were matched with the serial number of the forest village listed in each Division of Forest, and were selected for the survey.

Among the 52 forest villages, the average number of households per village was about 120 . We surveyed 10 houses randomly per village. The selection of households in a particular village was again done with the help of random numbers generated through a scientific calculator in which the total number of households in that particular village had been taken as the upper limit. The first ten random numbers generated were considered and the households corresponding to those generated numbers in a particular village were visited and the residents were questioned about conflict animals 
causing problem. Thus the data obtained from 520 households, animals causing depredation were identified and listed. Only the prominent species, which could be identified by a villager was listed up to species level, otherwise, the animal was identified till the genus level; e.g., there are four species of civets in the Barak Valley (Choudhury, 1997); whenever we came across, we refereed only civet. We listed the occurrence of conflict of the animal species separately and in different combinations (see Tables 1-5). For statistical analysis, chi-square test was performed.

\section{RESULTS}

The forest village dwellers mainly suffer from conflicts with Golden jackal (Canis aureus), Civets (Viverricula indica, Paradoxus hamiltonis, Paguma larvata, Viverra zibetha), Rhesus monkey (Macaca mulata) and wild boars (Sus scorfa) (Tables 1-5). The forest villages visited in Cachar Division were located under Hawaithang Range (12), Monierkhal Range (4), Jirighat Range (3) and Sadar Range (1). However, all the four conflict animals were found only in the two former Ranges, while only monkey depredation was found in Sadar Range, and except for monkey all three animal species depredation was recorded in Jirighat Range (Table 1). In Hailakandi Division, the forest villages were located under Matijuri (8) and Gharmurah Ranges (2). Both the ranges had all the four conflict animals (Table 2). In Karimganj Division, the villages were located under Cheragi (8) and Lowairpoa (14). Wild boars were completely absent from this Division (Table 3 ).

Depredation by wildlife is a common phenomenon in forest villages of Barak Valley as only two villages (i.e. Borthal and Noorka) we studied were devoid of any such problems. Combined depredation by jackals and civets is the most commonly prevalent phenomenon and 26 villages were recorded to have these predators (Table 4). In fact, the occurrence of these two conflict animals together is significantly higher than the occurrence of any other conflict animals occurring together $\left(\div^{2}=40.96, \mathrm{df}=4, \mathrm{P}<\right.$ $0.01))$. This is followed by the combined depredation by jackals, civets and monkeys as well as the composite depredation by jackals, civets, monkeys and wild boars which were recorded from seven villages each. The villages with all the four conflict

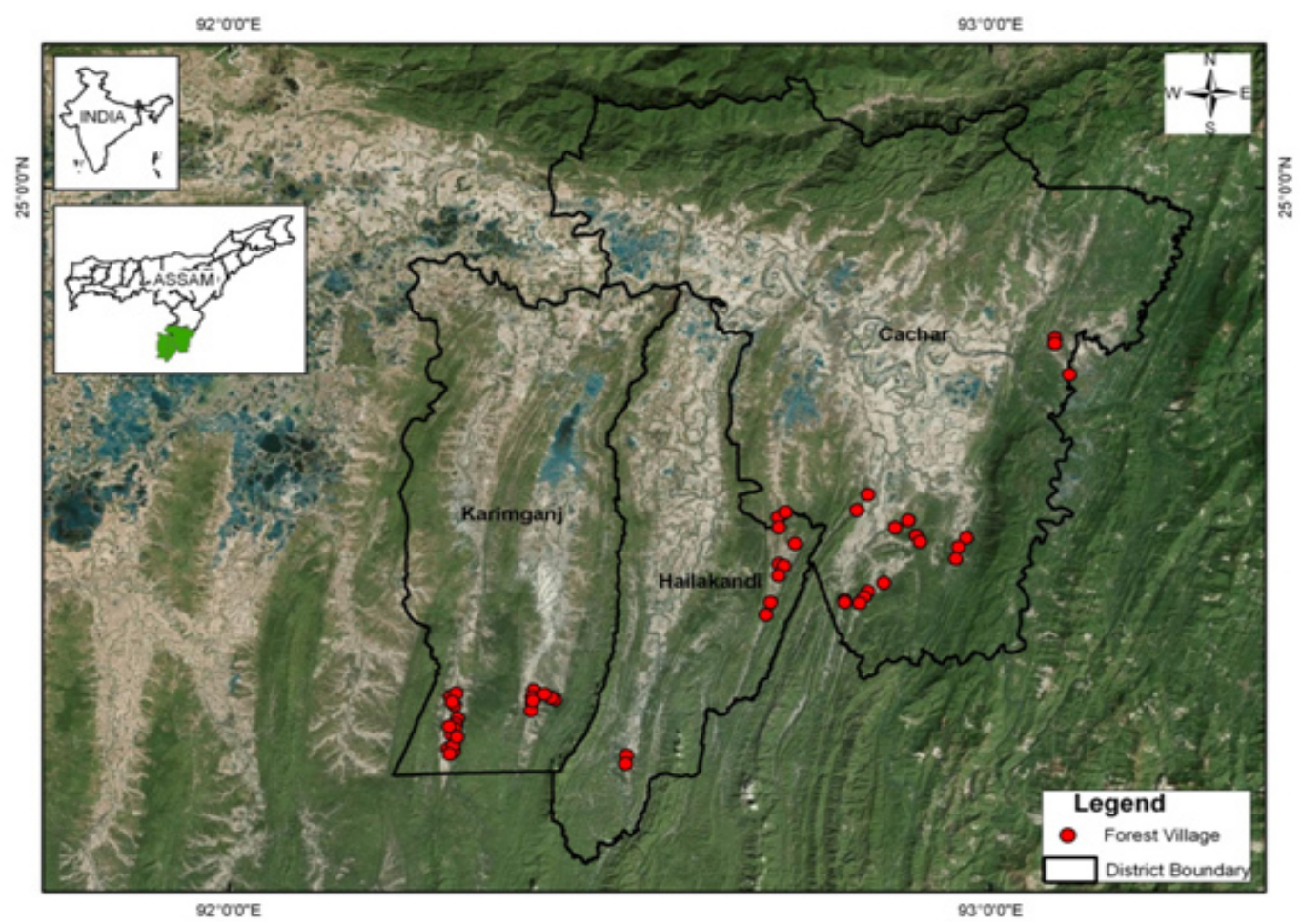

Fig. 1: Forest villages surveyed in three districts of Barak Valley, Assam. 
animals were Kulicherra, Jamalpur, Bagewala and Tulartol under Dholai Range, Chekercham under Monierkhal Range, Gharmurah under Gharmurah Range and Dhalcherra under Matijuri Range. Khulicherra, Jamalpur, Tulartol, Gharmurah and Dhalcherra are located within Innerline reserve forest whereas Chekercham and Smithnagar II are located within Barak and Sonai reserve forests, respectively (Table 4).

Human conflicts with jackals, civets and monkeys were found to take place in all the three Divisions whereas those with wild boars were confined only to Cachar and Karimganj (Table 5). Jackal depredation dominated in Cachar (18 villages) whereas civet depredation dominated in Karimganj (21 villages). Both jackals and civets together cause depredation in disturb the highest number of villages in Hailakndi (nine villages each). On the other hand, as a whole, jackal, which has been involved in conflicts with the residents of 47 villages, has been found to be the most common conflict animal whereas civets that infest 46 villages closely followed. In fact, the individual occurrence of jackals and civets as a whole was significantly more as compared to monkeys and wild boars $\left(\div^{2}=33.74\right.$, $\mathrm{df}=3, \mathrm{P}<0.01))($ Table 5)

\section{DISCUSSION}

According to Datta-Roy et al. (2009), there are four different situations when wild animals can come into conflict with humans: (i) direct threat to human life, (ii) destruction of property by wild animals, (iii) direct competition for forage between domestic livestock and wild herbivores, and (iv)

Table 1: presence of conflict animals in the forest villages surveyed in cachar division (a total of 20 forest villages surveyed)

\begin{tabular}{|c|c|c|c|c|c|c|}
\hline \multirow{2}{*}{\multicolumn{2}{|c|}{$\begin{array}{l}\text { Name of the forest } \\
\text { villages }\end{array}$}} & \multirow{3}{*}{$\begin{array}{c}\text { Forest Ranges } \\
\text { Hawaithang }\end{array}$} & \multicolumn{4}{|c|}{ Conflict animals } \\
\hline & & & \multirow{2}{*}{ RhesusMonkey } & \multirow{2}{*}{$\begin{array}{c}\text { Golden Jackal } \\
\mathrm{P}\end{array}$} & \multirow{2}{*}{$\frac{\text { Civets }}{\mathrm{P}}$} & \multirow{2}{*}{$\frac{\text { Wild boal }}{P}$} \\
\hline 1. & Bagewala & & & & & \\
\hline 2. & Barmannagar & Hawaithang & $\mathrm{P}$ & & & \\
\hline 3. & Bhubander & Hawaithang & $\mathrm{P}$ & $P$ & $\mathrm{P}$ & \\
\hline 4. & Dhanipur & Hawaithang & & $\mathrm{P}$ & $\mathrm{P}$ & \\
\hline 5. & Gurudayalpur & Hawaithang & & $P$ & & \\
\hline 6. & Jamalpur & Hawaithang & $P$ & $P$ & $P$ & $P$ \\
\hline 7. & Jarultola & Hawaithang & & $\mathrm{P}$ & $P$ & \\
\hline 8. & Kulicherra & Hawaithang & $\mathrm{P}$ & $\mathrm{P}$ & $\mathrm{P}$ & $\mathrm{P}$ \\
\hline 9. & Mohanpur & Hawaithang & & $\mathrm{P}$ & $\mathrm{P}$ & \\
\hline 10. & Radhanagar & Hawaithang & & $\mathrm{P}$ & $\mathrm{P}$ & \\
\hline 11. & Ramprasadpur & Hawaithang & & $\mathrm{P}$ & $\mathrm{P}$ & \\
\hline 12. & Tulartol & Hawaithang & $\mathrm{P}$ & $\mathrm{P}$ & $\mathrm{P}$ & $\mathrm{P}$ \\
\hline 13. & Baghkhal & Jirighat & & $\mathrm{P}$ & $\mathrm{P}$ & $\mathrm{P}$ \\
\hline 14. & Khoirabad & Jirighat & & $\mathrm{P}$ & $P$ & \\
\hline 15. & New Khoirabad & Jirighat & & $\mathrm{P}$ & & $\mathrm{P}$ \\
\hline 16. & Chekercham & Monierkhal & $\mathrm{P}$ & $\mathrm{P}$ & $\mathrm{P}$ & $\mathrm{P}$ \\
\hline 17. & Smithnagar I & Monierkhal & & $\mathrm{P}$ & $P$ & $\mathrm{P}$ \\
\hline 18. & Smithnagar II & Monierkhal & $\mathrm{P}$ & $\mathrm{P}$ & $P$ & $\mathrm{P}$ \\
\hline 19. & Zurkhal & Monierkhal & & $P$ & $\mathrm{P}$ & $\mathrm{P}$ \\
\hline 20. & Loharbond & Sadar & $\mathrm{P}$ & & & \\
\hline
\end{tabular}

Golden jackal (Canis aureus), Civets (Viverricula indica, Paradoxus hamiltonis, Paguma larvata, Viverra zibetha), Rhesus monkey (Macaca mulata) and Wild Boar (Sus scorfa). 'P' denotes presence of the animal in the respective column. 
damage of agricultural crops by wild animals. Of these, the third and fourth frequently occur in the forest villages of Barak Valley.

Dwellers of forest villages in the Barak Valley suffer from conflicts with animals such jackals, civets, monkeys and wild boars of which the former two are the most common and are involved in livestock depredation. Predation on domestic livestock is likely to hamper coexistence between people and large carnivores (Espuno et al., 2004; Ogada et al., 2003). However, in most of the cases, combined depredation by jackals and civets was prevalent. In addition to reports of livestock, a case of human attack by jackal was documented from Belaipur forest village under Matijuri Range, Hailakandi Division.

Rhesus macaques (Macaca mulatta) raid crops and vegetables and were also involved in menace within households. In fact, crop raiding by Rhesus macaque is a serious problem (Miah et al., 2001). On the other hand, wild boars destroy paddy fields. Human conflict with wild boars has been increasing around protected areas, managed forests and human settlements all over India (Chauhan et al., 2009). All these animals emerge throughout the year from the wilds whereas wild boars were involved in conflicts only during winter months when they come out to raid ripe crop fields.

There were usually combined depredations by multiple conflict animals in forest villages. In other words, a particular village was disturbed by more than one species of wild animal. However, seven villages stand out as the ones which suffer the most since they witness conflicts with all four conflict animals whereas only two do not witness conflicts of any kind with any of the wild animals.

Noorka village which is inhabited only by Bishnupuria Manipuri communities provides no scope for depredation by carnivores since the residents only rear cows and buffalos which could not be predated upon by jackals and civets. Monkeys and wild boars are absent in the village. On the other hand, all the conflict animals are absent from Borthal.

However, in addition to these regular wild animals, forest villagers also face economic losses due to squirrels and hares which feed upon home garden plants and destroy home gardens; mongooses which not only kill livestock but also damage paddy fields by burrowing; jungle fowls peck sown paddy seeds. Leopards have also made

Table 2: presence of conflict animals in the forest villages of hailakandi division (a total of 10 forest villages surveyed)

\begin{tabular}{|c|c|c|c|c|c|c|}
\hline \multirow{2}{*}{\multicolumn{2}{|c|}{$\begin{array}{l}\text { Name of the forest } \\
\text { villages }\end{array}$}} & \multirow[b]{2}{*}{ Forest Ranges } & \multicolumn{4}{|c|}{ Conflict animals } \\
\hline & & & \multirow[t]{2}{*}{ RhesusMonkey } & \multirow{2}{*}{$\begin{array}{c}\text { Golden Jackal } \\
\text { P }\end{array}$} & \multirow{2}{*}{$\begin{array}{c}\text { Civets } \\
\mathrm{P}\end{array}$} & \multirow[t]{2}{*}{ Wild boar } \\
\hline 1. & Belaipur & Matijuri & & & & \\
\hline 2. & Borthal & Matijuri & & & & \\
\hline 3. & Dhalcherra & Matijuri & $\mathrm{P}$ & $\mathrm{P}$ & $\mathrm{P}$ & $\mathrm{P}$ \\
\hline 4. & Dhalcherra T.P. & Matijuri & & $\mathrm{P}$ & $\mathrm{P}$ & \\
\hline 5. & Gharmurah & Gharmurah & $\mathrm{P}$ & $\mathrm{P}$ & $\mathrm{P}$ & $\mathrm{P}$ \\
\hline 6. & Jacobpur & Gharmurah & & $\mathrm{P}$ & $P$ & $P$ \\
\hline 7. & Lalpani & Matijuri & & $\mathrm{P}$ & $\mathrm{P}$ & \\
\hline 8. & Nuagaon & Matijuri & & $\mathrm{P}$ & $\mathrm{P}$ & \\
\hline 9. & Old baghbahar & Matijuri & & $\mathrm{P}$ & $\mathrm{P}$ & \\
\hline 10. & Pratappur & Matijuri & & $\mathrm{P}$ & $\mathrm{P}$ & \\
\hline
\end{tabular}

Golden jackal (Canis aureus), Civets (Viverricula indica, Paradoxus hamiltonis, Paguma larvata, Viverra zibetha), Rhesus monkey (Macaca mulata) and Wild Boar (Sus scorfa). 'P' denotes presence of the animal in the respective column 
Table 3: presence of conflict animals in the forest villages surveyed in karimganj division (a total of 22 forest villages surveyed)

\begin{tabular}{|c|c|c|c|c|c|c|}
\hline \multirow{2}{*}{\multicolumn{2}{|c|}{$\begin{array}{l}\text { Name of the forest } \\
\text { villages }\end{array}$}} & \multirow{3}{*}{$\begin{array}{c}\text { Forest Ranges } \\
\text { Cheragi }\end{array}$} & \multicolumn{4}{|c|}{ Conflict animals } \\
\hline & & & \multirow[t]{2}{*}{ RhesusMonkey } & \multirow{2}{*}{$\begin{array}{c}\text { Golden Jackal } \\
\text { P }\end{array}$} & \multirow{2}{*}{$\begin{array}{c}\text { Civets } \\
\mathrm{P}\end{array}$} & \multirow{2}{*}{ Wild boar } \\
\hline 1. & Bhutucherra (D) & & & & & \\
\hline 2. & Bhutucherra (M) & Cheragi & $\mathrm{P}$ & $\mathrm{P}$ & $\mathrm{P}$ & \\
\hline 3. & Bhutucherra $(\mathrm{T})$ & Cheragi & & $P$ & $\mathrm{P}$ & \\
\hline 4. & Bijoypur & Cheragi & & $\mathrm{P}$ & $\mathrm{P}$ & \\
\hline 5. & Birojapur & Cheragi & $\mathrm{P}$ & $\mathrm{P}$ & $\mathrm{P}$ & \\
\hline 6. & Kakurapunjee & Cheragi & $\mathrm{P}$ & $\mathrm{P}$ & $\mathrm{P}$ & \\
\hline 7. & Kishoripur & Cheragi & $\mathrm{P}$ & $\mathrm{P}$ & $\mathrm{P}$ & \\
\hline 8. & Rajendrapur & Cheragi & & $\mathrm{P}$ & $\mathrm{P}$ & \\
\hline 9. & Adityanagar & Lowairpoa & & $\mathrm{P}$ & $\mathrm{P}$ & \\
\hline 10. & Balipipla & Lowairpoa & & & $\mathrm{P}$ & \\
\hline 11. & Jacobnagar & Lowairpoa & & $\mathrm{P}$ & $\mathrm{P}$ & \\
\hline 12. & Kanakpur & Lowairpoa & & $\mathrm{P}$ & $\mathrm{P}$ & \\
\hline 13. & Magurapunjee & Lowairpoa & & $\mathrm{P}$ & $\mathrm{P}$ & \\
\hline 14. & Manikband (Mahi) & Lowairpoa & & $\mathrm{P}$ & $\mathrm{P}$ & \\
\hline 15. & Manikband- Punjee & e Lowairpoa & & $\mathrm{P}$ & $\mathrm{P}$ & \\
\hline 16. & Nandirgram & Lowairpoa & $\mathrm{P}$ & $\mathrm{P}$ & $\mathrm{P}$ & \\
\hline 17. & Nilkanthapur & Lowairpoa & $\mathrm{P}$ & $\mathrm{P}$ & $\mathrm{P}$ & \\
\hline 18. & Noorka & Lowairpoa & & & & \\
\hline 19. & North Magura & Lowairpoa & & $\mathrm{P}$ & $\mathrm{P}$ & \\
\hline 20. & Proper Magura & Lowairpoa & & $\mathrm{P}$ & $\mathrm{P}$ & \\
\hline 21. & Rangamati & Lowairpoa & & $\mathrm{P}$ & $\mathrm{P}$ & \\
\hline 22. & South Magura & Lowairpoa & & $\mathrm{P}$ & $\mathrm{P}$ & \\
\hline
\end{tabular}

Golden jackal (Canis aureus), Civets (Viverricula indica, Paradoxus hamiltonis, Paguma larvata, Viverra zibetha), Rhesus monkey (Macaca mulata) and Wild Boar (Sus scorfa). 'P' denotes presence of the animal in the respective column.

Table 4: number of forest villages where conflict animals in different combinations occurred under forest divisions in barak valley, assam during 2013-2014

\begin{tabular}{|c|c|c|c|c|c|c|c|c|c|}
\hline Division & $\begin{array}{c}\text { No } \\
\text { conflict }\end{array}$ & Jackal & Civet & Monkey & $\begin{array}{c}\text { Jackal } \\
\& \\
\text { Civet }\end{array}$ & $\begin{array}{c}\text { Jackal } \\
\& \\
\text { Wild boar \& }\end{array}$ & $\begin{array}{l}\text { Jackal, } \\
\text { Civet } \\
\text { Monkey }\end{array}$ & $\begin{array}{c}\text { Jackal, } \\
\text { Civet\& } \\
\text { Wild } \\
\text { boar }\end{array}$ & $\begin{array}{c}\text { Jackal, } \\
\text { Civet, } \\
\text { Monkey } \\
\text { \& Wild boar }\end{array}$ \\
\hline Cachar & 0 & 1 & 0 & 2 & 6 & 1 & 1 & 4 & 5 \\
\hline Hailakndi & 1 & 0 & 0 & 0 & 6 & 0 & 0 & 1 & 2 \\
\hline Karimganj & 1 & 0 & 1 & 0 & 14 & 0 & 6 & 0 & 0 \\
\hline Total & 2 & 1 & 1 & 2 & 26 & 1 & 7 & 5 & 7 \\
\hline
\end{tabular}


Table 5: occurence of four conflict animals in $\mathbf{5 2}$ forest villages under three forest divisions in barak valley, assam during 2013-2014.

\begin{tabular}{lcccc}
\hline Villages visited & Cachar & Hailakandi & Karimganj & Total \\
\hline & 20 & 10 & 22 & 52 \\
Jackal depredation & 18 & 9 & 20 & 47 \\
Civet depredation & 16 & 9 & 21 & 46 \\
Monkey depredation & 8 & 2 & 6 & 16 \\
Wild boar depredation & 10 & 3 & 0 & 13 \\
\hline
\end{tabular}

their presence felt in two villages (Bagewala and Zurkhal) during the last decade but their occurrence was rare as compared to the other conflict animals. In addition to these, phayer's leaf monkey gives rise to moderate conflict situations in a village named Ramprasadpur situated in the Innerline reserve forest under Hawaithang Range.

Hence, it is concluded that frugivores, herbivores and carnivores are involved in conflicts with the residents of the forest villages of Barak Valley. This problem is likely to complicate conservation and management efforts and hence this problem must be properly addressed in the region. Although the conflict animals involved are not endangered, the intensity of their depredations at times surpass the economic threshold of the victims and this has a negative impact upon public perception on these animals.

\section{ACKNOWLEDGEMENT}

We are thankful to the Forest Departments of the three Divisions of Barak Valley, Assam for providing necessary permission for research as well as for providing necessary assistance during fieldwork. The co-operation received from the local residents of the surveyed forest villages is also highly acknowledged. We are further thankful to Prof. Jayashree Rout, Head, Department of Ecology \& Environmental Science, Assam University, Silchar for her support.

\section{REFERENCES}

1. Conover M., Resolving human-wildlife conflicts: the science of wildlife damage management. Lewis Publishers CRC Press Company, Boca Raton Florida, USA (2002).

2. Graham K., Beckerman A. P. and Thirgood S. J., Biol. Conserv., 122(2), 159-171 (2005).

3. Woodroffe R., Thirgood S. and Rabinowitz A. People and Wildlife: Conflict or Coexistence?. Cambridge University Press, Cambridge, UK, 1-12 (2005).

4. Ministry of Environment and forest, India, Report of the Working Group on Wildlife, Ecotourism and Animal Welfare for the $12^{\text {th }}$ Five Year Plan 2012-2017, Submitted to Planning Commission, Government of India, New Delhi, (2011).

5. Sukumar R., J. Trop. Ecol., 6, 33-53 (1990).

6. Mishra C., High altitude survival: conflicts between pastoralism and wildlife in the trans-Himalaya. Ph.D. thesis, Wageningen
University, The Netherlands (2001).

7. Saberwal, V. K., Gibss, J. P., Chellam, R. and Johnsingh, A. J.T., Conserv. Biol., 8, 501-507 (1994).

8. Champion H. G. and Seth S. K., Forest types of India. Dehradun: Forest Research Institute (1968).

9. Das P. and Joshi S., Envis Assam (OctoberDecember), 2-7 (2012).

10. Choudhury A., The mammals of northeast India, $1^{\text {st }}$ Edition, Gibbon Books, Guwahati, India and The Rhino Foundation in NE India (2013).

11. Fanning E., Practical Assessment Research and Evaluation 10(12), 1-14 (2005).

12. Anon. 2012. Survey Questionnaire Design. Available at: http://www.fairfaxcounty.gov/ demogrph/pdf/questionnairedesign.pdf [Date Accessed: 12 August, 2012].

13. Choudhury A., Checklist of the mammals of 
Assam, 2 ${ }^{\text {nd }}$ Edition, Gibbon Books, Guwahati, India with Assam Science Technology and Environmental Council (1997).

14. Datta-Roy A., Ved N. and Williams A. C., Trop. Ecol., 50(1), 163-171 (2009).

15. Espuno, N., Lequette, B., Poulle, M. L., Migot, P. and Lebreton, J. D., Wildl. Soc. Bull., 32, $1195 " 1208$ (2004).
16. Ogada, M. O., Woodroffe, R., Oguge, N. O. and Frank, L. G., Conserv. Biol., 17, 1521"1530 (2003).

17. Miah D. Md., Rahman L. Md. and Ahsan F Md., Tigerpaper, 28(4), 22-28 (2001).

18. Chauhan N. P. S., Barwal K.S. and Kumar D., Acta Silv Lign Hung, 5, 189-197 (2009). 